
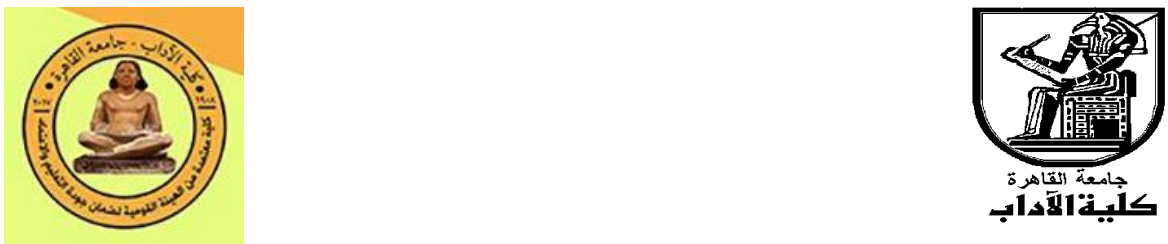

Center for Research and Historical Studies Faculty of Arts- Cairo University

\title{
Historical Events
}

A Semi Annual Journal

Issued by Center for Research and Historical Studies

\section{Prof. Jamal El-Shazly \\ Dean of the College and Chairman of the Board of Directors}

\section{Prof.Dr. Ragab Salama Omran Editor -in- Chief}

Thirty TOW (Tome II)

January 2020 



\section{Board of Editors}

- Prof.Dr. Gamal El-Shazly

- Prof.Dr. Raja Ahmed Ali

- Prof.Dr. Ragab Salama Omran

- Prof.Dr. Zubaida Atta

- Prof.Dr. Zakaria Sadiq Al-Rifa

- Prof.Dr. Hamed Ziyan Ghanem

- Prof.Dr. Mahmoud Arafa Mahmoud

- Prof.Dr. Ahmed Ragab Mohamed Ali
Dean of the College and Chairman of the Board of Directors

Vice President for Community Service Affairs and Vice Chairman of the Board of Directors

Editor -in- Chief

Helwan University

Mansoura University

Cairo University

Cairo University

Faculty of Archeology, Cairo University

- Prof.Dr. Mohamed Afifi Abdel- Cairo University Khalek

- Prof.Dr. Wajih Abdul-Sadiq Ateeq Cairo University

- Prof.Dr. Iman Abdel Moneim Amer

- prof.mag.dr.Ekkehard Weber
Cairo University

Member of the University of Vienna 
